\title{
Rapid method for determination of DNA repair capacity in human peripheral blood lymphocytes amongst smokers
}

\author{
Randa A El-Zein ${ }^{1 *}$, Claudia M Monroy ${ }^{1}$, Andrea Cortes $^{1}$, Margaret R Spitz ${ }^{1}$, Anthony Greisinger ${ }^{2}$, Carol J Etzel ${ }^{1}$
}

\begin{abstract}
Background: DNA repair capacity is an important determinant of susceptibility to cancer. The hOGG1 enzyme is crucial for repairing the 8-oxoguanine lesion that occurs either as a byproduct of oxidative metabolism or as a result of exogenous sources such as exposure to cigarette smoke. It has been previously reported that smokers with low hOGG1 activity had significantly higher risk of developing lung cancer as compared to smokers with high hOGG1 activity.

Methods: In the current study we elucidate the association between plasma levels of 8-OHdG and the OGG1 repair capacity. We used the commercially available 8-OHdG ELISA (enzyme-linked immunosorbent assay), the Comet assay/FLARE hOGG1 (Fragment Length Analysis by Repair Enzymes) assay for quantification of the levels of 8-OHdG and measured the constitutive, induced and unrepaired residual damage, respectively. We compared the DNA repair capacity in peripheral blood lymphocytes following $\mathrm{H}_{2} \mathrm{O}_{2}$ exposure in 30 lung cancer patients, 30 non-, 30 former and 30 current smoker controls matched by age and gender.
\end{abstract}

Results: Our results show that lung cancer cases and current smoker controls have similar levels of 8-OHdG lesions that are significantly higher compared to the non-smokers controls. However, lung cancer cases showed significantly poorer repair capacity compared to all controls tested, including the current smokers controls. After adjustment for age, gender and family history of smoking-related cancer using linear regression, we observed a 5 -fold increase in risk of lung cancer associated with high levels of residual damage/reduced repair capacity.

Reduced OGG1 activity could be expected to be a risk factor in other smoking-related cancers.

Conclusion: Our study shows that the Comet/FLARE assay is a relatively rapid and useful method for determination of DNA repair capacity. Using this assay we could identify individuals with high levels of residual damage and hence poor repair capacity who would be good candidates for intensive follow-up and screening.

\section{Background}

DNA repair is a ubiquitous defense mechanism that is critical to maintaining the integrity of the genome. Several prior studies have reported associations between reduced repair capacity and cancer development [1-3]. Base excision repair (BER) is the main pathway involved in the repair of oxidative DNA damage and recent studies have indicated a correlation between reduced BER capacity and oncogenesis $[4,5]$. The oxidative DNA damage induced by reactive oxygen species (ROS) may

\footnotetext{
* Correspondence: relzein@mdanderson.org

${ }^{1}$ The University of Texas M. D. Anderson Cancer Center, Department of Epidemiology, Houston, Texas, USA

Full list of author information is available at the end of the article
}

lead to single- or double-strand breaks, point and frame-shift mutations and larger-scale chromosome abnormalities [6]. ROS can be formed endogenously as a result of xenobiotic metabolism by cytochrome P450 enzymes, by redox cycling of hormone metabolites or exposure to other environmental factors [7].

Smoking is an inducer of oxidative stress which results in ROS-induced DNA damage [8] in the form of DNA adducts. This may be of particular importance in lung cancer where increased oxidative DNA damage coupled with reduced BER may play an important role in modifying the disease risk [9]. It is well know that only a small percentage of smokers develop lung cancer [10] 
suggesting that individual DNA repair capacity may play a significant role in the carcinogenic process.

The 8-oxoguanine DNA glycosylase (hOGG1) is one of the key DNA repair enzymes involved in the BER pathway in humans $[11,12]$. It recognizes the 8-oxoguanine modifications from both nuclear and mitochondrial DNA [13]. Among the more than 30 different products of modified DNA and RNA by oxidative damage [14], 8Hydroxy-2'-deoxyguanosine (8-OHdG) is the most extensively studied induced lesion. 8-OHdG lesion causes $\mathrm{G} \rightarrow \mathrm{T}$ and $\mathrm{A} \rightarrow \mathrm{C}$ transversions [15] that have been reported as the sites of spontaneous oncogene expression and ultimately cancer manifestation $[16,17]$. Deletion of the hOGG1 gene was shown to be associated with accumulation of 8-OHdG lesion and increase in mutational risk [18]. OGG1 deficiency in yeast was shown to result in a spontaneous mutator phenotype [19]. Collins et al observed a lack of repair activity on a DNA substrate containing 8-OHdG protein extracts from homozygous OGG1 knockout mouse embryonic fibroblasts [20]. In contrast, mammalian cells over-expressing OGG1 repair 8-OHdG more rapidly after toxic insult with oxidants [21]. Increased levels of 8-OHdG has been associated with an increased risk of lung cancer among smokers [22]. In a recent study, PazElizur et al evaluated the enzymatic OGG1 activity among smoking lung cancer cases and controls. The authors reported that the OGG1 activity was significantly decreased in lung cancer cases, and that the risk of developing lung cancer in smokers with low OGG1 activity was significantly higher compared to smokers with high OGG1 activity [23]. To date, the association between the levels of 8-OHdG and OGG1 repair capacity has not been determined.

In the current study we hypothesized that an inverse association exists between the levels of 8-OHdG and OGG1 activity. Furthermore, we hypothesized that lung cancer patients have higher levels of 8-OHdG reflecting suboptimal OGG1 repair capacity when compared to healthy controls. To test these hypotheses, we quantified the levels of 8-OHdG and measured ROS-induced DNA damage and repair in peripheral blood lymphocytes of lung cancer cases and controls. We used the commercially available 8-OHdG ELISA (enzyme-linked immunosorbent assay) to measure the levels of 8-OHdG in plasma and the Comet assay and hOGG1 FLARE (Fragment Length Analysis by Repair Enzymes) assay to measure the constitutive, induced and unrepaired residual damage by measuring DNA strand breaks and abasic sites. The Comet assay is used to detect DNA damage (including single-strand breaks, double-strand breaks and alkali-labile sites) [24,25] as well as to determine interindividual variation in DNA repair capacity through the measurement of residual DNA damage after exposure to mutagens [26,27]. The hOGG1 FLARE is a modified Comet assay that employs 8-oxoguanine DNA glycosylase to recognize and nick the DNA specifically at the 8-OHdG lesion thus resulting in strand breaks [28]. Cells not exposed to hOGG1 serve as a baseline for naturally occurring DNA breaks; while cells exposed to hOGG1 contain both naturally occurring breaks in DNA, as well as breaks caused by hOGG1 at places containing unrepaired 8-OHdG adducts [29]. Our results show that lung cancer cases and current smoker controls had higher levels of 8-OHdG compared to the former and non-smokers controls. Similarly, our results demonstrated that baseline DNA damage is comparable between lung cancer cases and current smoker controls but is significantly higher than that observed among former smokers and non-smokers controls. Further investigation revealed that lung cancer cases showed significantly poorer repair capacity than that observed in current smoker controls suggesting impairment of adduct removal. In conclusion, our study shows that the Comet/FLARE assay is a relatively rapid and useful method for determination of DNA repair capacity and that adduct removal by OGG1 is a mechanism that might be significantly impaired among smokers who develop lung cancer. Using this assay we could potentially identify individuals with high levels of residual damage and hence poor repair capacity. Identification of the small percentage of susceptible smokers with poor repair would allow for better prevention interventions.

\section{Methods}

\section{Study population}

A total of 120 participants were included in the study. Thirty smoker lung cancer patients were recruited from The University of Texas M. D. Anderson Cancer Center as part of an ongoing lung cancer case-control study. The patients had newly diagnosed, histologically confirmed lung cancer with no prior history of treatment (radiation or chemotherapy) upon enrollment in the study. Controls $(n=90)$ were matched to cases on age $(+/-5$ years $)$ and gender and were recruited from the Kelsey-Seybold Clinics in Houston, Texas. The control participants consisted of 30 non-smokers, 30 former smokers and 30 current smokers with no previous history of cancer. After informed consent was obtained, a personal interview was conducted and information regarding socio-demographics, smoking history, alcohol consumption, occupational exposures, diet and family history of cancer was collected. There were no age and gender restrictions for study eligibility. The institutional review boards at both M. D. Anderson Cancer Center and Kelsey-Seybold Clinic approved this study. After providing informed consent, $10-\mathrm{mL}$ blood was collected from all study participants. 


\section{Peripheral blood lymphocyte isolation}

Peripheral blood and lymphocytes were isolated using standard Ficoll-Histopaque method. Briefly, $10 \mathrm{ml}$ of whole blood from each subject was drawn into heparinized tubes, layered over $10 \mathrm{ml}$ of Histopaque -1077 (Sigma Aldrich Co., St. Louis, MO) at room temperature and centrifuged at $1500 \mathrm{rpm}$ for $30 \mathrm{~min}$. The mononuclear cells were removed from the interphase, washed twice with phosphate-buffered saline $\mathrm{pH} 7.2$ and centrifuged at 1500 rpm for $10 \mathrm{~min}$. Cells were suspended in $1 \mathrm{ml}$ of RPMI 1640 medium and the cell membrane integrity was determined by Trypan Blue solution $0.4 \%$ and adjusted to a concentration of $1 \times 10^{6}$ cells $/ \mathrm{ml}$. Duplicate lymphocyte cultures were prepared for each study subject. Lymphocytes were then resuspended in RPMI 1640 medium supplemented with $1 \%$ L-glutamine, $100 \mathrm{U} / \mathrm{ml}$ of penicillin and of streptomycin (Gibco Invitrogen Corp., Grand Island, NY), 10\% fetal calf serum, 2\% PHA (Murex Biotech Ltd., Dartford, England, UK) and cultured in 24-well microplates for $24 \mathrm{~h}$ at $37^{\circ} \mathrm{C}$ in $5 \% \mathrm{CO}_{2}$ prior to treatment.

\section{Establishment of hydrogen peroxide $\left(\mathrm{H}_{2} \mathrm{O}_{2}\right)$ treatment conditions}

We used $\mathrm{H}_{2} \mathrm{O}_{2}$ as the ROS-inducing agent in vitro. In order to establish the optimal conditions for exposure and repair kinetics, peripheral blood lymphocytes were isolated from 20 healthy controls. A dose-response curve was generated using in vitro treatment of lymphocytes with $\mathrm{H}_{2} \mathrm{O}_{2}$ (at a range of concentrations between 20-100 $\mu \mathrm{M}$ ) for 15 min. Results from the dose response curve indicated that the $60 \mu \mathrm{M}$ concentration, lead to a cell viability $>85 \%$ and DNA damage that was significantly higher than the negative control $(\mathrm{P}<0.001)$ (Additional file 1, Figure S1A).

The cells concentration was adjusted to $3 \times 10^{4}$ cells/ $\mathrm{ml}$ and suspended in RPMI 1640 medium without FBS, supplemented with $2 \mathrm{mM}$ L-glutamine, $100 \mathrm{U} / \mathrm{ml}$ of penicillin/streptomycin and 20\% Alamar Blue cell assay ${ }^{\mathrm{rm}}$ (BioSource International Inc., Camarillo, CA, USA) to determine metabolic activity/cell viability of the cells. The cell viability was measured for each time of treatment with a spectrophotometer (Tecan, Genios Pro) at $535 \mathrm{~nm}$ excitation and $590 \mathrm{~nm}$ emission. Using Pearson's correlation we estimated the correlation between the most common parameters reported in the literature to determine damage by the Comet assay namely: the tail extent moment (TEM) and the tail length (TL). Our results indicated a pair-wise correlation of $R^{2}=0.94$ $0.96(\mathrm{P}<0.001)$ and therefore in the following sections we reported our findings using the TEM only.

\section{Optimization of recovery time for $\mathrm{H}_{2} \mathrm{O}_{2}$-induced damage/ repair}

A normal lymphoblastoid cell line (AH, [cat\#GM14520], Coriell Cell Repositories, Camden, NJ, USA) was used to determine the optimal incubation time for recovery of in vitro $\mathrm{H}_{2} \mathrm{O}_{2}$-induced damage. Significant DNA damage TEM was observed after 15 min $\mathrm{H}_{2} \mathrm{O}_{2}$-treatment as compared to the untreated cells (mean $+\mathrm{SD}=$ $0.89+0.18$ versus $0.47+0.07$ respectively, $\mathrm{P}=0.002)$. After $1 \mathrm{~h}$ incubation at $37^{\circ} \mathrm{C}$ to allow the cells to recover, a significant reduction in TEM was observed as compared to the $\mathrm{H}_{2} \mathrm{O}_{2}$-treated cells (mean $\pm \mathrm{SD}=0.65$ \pm 0.11 versus $0.89 \pm 0.18$ respectively, $\mathrm{P}=0.007$ ); however the damage was still significantly higher than that observed in the untreated cells (mean $+\mathrm{SD}=0.65+$ 0.11 versus $0.47+0.07$ respectively, $\mathrm{P}=0.01$ ). Incubation of the cells for $2 \mathrm{~h}$ at $37^{\circ} \mathrm{C}$ showed a further reduction in the level of measured TEM when compared to the $1 \mathrm{~h}$ incubation (mean $\pm \mathrm{SD}=0.51 \pm 0.05$ versus $0.65 \pm 0.11$, respectively); however these differences were not statistically significant and we therefore decided to use the one-hour incubation in our subsequent experiments in order to accommodate the further experimental procedures that included a further incubation with the hOGG1 enzyme followed by denaturation and electrophoresis (Additional file 1, Figure S1B).

\section{Measurement of 8-OHdG levels}

Baseline serum levels of 8-OHdG was measured using the commercially available 8-OHdG ELISA Kit (BIOXY$\mathrm{TECH}^{\odot} \mathrm{OXIS}$ International Inc., Foster City, CA, USA) following manufacturer's recommendations. This kit is a competitive ELISA for quantitative measurement of 8OHdG in tissue, serum or plasma resulting from oxidative damage to DNA.

\section{Comet/FLARE ${ }^{\circledR}$ assay}

Collins et al [20] first introduced this technique to study BER pathway. The principal of this assay depends on incubating cell extracts with a substrate of DNA containing specific lesions. Incubation of the substrate DNA with the specific enzymes allows for the uncovering of specific damaged bases. Treating lysed, immobilized cells with a DNA glycosylase, converts the base to an alkali sensitive site, followed by DNA unwinding that allows additional damage to be recognized. This leads to the introduction of breaks that are measured using the single-cell gel electrophoresis (Comet) assay. On the basis of the initial results, the lymphocytes were treated with a concentration of $60 \mu \mathrm{M} \mathrm{H}_{2} \mathrm{O}_{2}$ in a total volume of $200 \mu \mathrm{M}$ RPMI at $4^{\circ} \mathrm{C}$ for $15 \mathrm{~min}$. Cells were then incubated at $37^{\circ} \mathrm{C}$ for $1 \mathrm{~h}$ to allow the cells to recover. The cell suspension was then aspirated from the wells and washed with PBS pH 7.2. Cells were then embedded in a layer of low melting point agarose (LMA) at $37^{\circ} \mathrm{C}$ prepared in PBS and the mixtures were immediately transferred to the FLARE ${ }^{\oplus}$-slides (Trevigen Inc.). Duplicate slides were prepared from each well. Slides were 
immersed in lysis solution $(2.5 \mathrm{M} \mathrm{NaCl}, 100 \mathrm{mM}$ EDTA $\mathrm{pH}$ 10, $10 \mathrm{mM}$ Tris base, $1 \%$ sodium lauryl sarcosinate, $1 \%$ Triton X-100 and 1\% DMSO) (Trevigen Inc.) for $1 \mathrm{~h}$ at $4^{\circ} \mathrm{C}$. The slides were washed in FLARE buffer (250 mM HEPES-KOH pH 7.4, $2.5 \mathrm{M} \mathrm{KCl}$ and $250 \mathrm{mM}$ EDTA) at room temperature three times over a $15 \mathrm{~min}$ period. $100 \mu \mathrm{l}$ of hOGG1 (1:500) was then added to each sample and incubated at $37^{\circ} \mathrm{C}$ for 40 min (following manufacturer's recommendations) to allow for further cell recovery. The DNA of the nuclei in the agarose gels was denatured in electrophoresis buffer $\mathrm{pH}$ 12.1 (3 M NaCl, $500 \mathrm{mM}$ EDTA) for $30 \mathrm{~min}$ at $4^{\circ} \mathrm{C}$. Electrophoresis was performed in alkaline solution $\mathrm{pH}$ 13 applying $300 \mathrm{~mA}, 25 \mathrm{~V}$ for $30 \mathrm{~min}$ at $4^{\circ} \mathrm{C}$. The slides were then placed in cold methanol for $20 \mathrm{~min}$, dried and stored in a slide box at room temperature. At time of analysis, the slides were hydrated in cold water at $4^{\circ} \mathrm{C}$ for $20 \mathrm{~min}$ and stained with ethidium bromide solution $(2 \mu \mathrm{g} / \mathrm{mL})$. Slides were coded in order to blind the treatment conditions from the scorer and 100 random cells/ sample were analyzed (50 cells/duplicate slide) using an epi-fluorescence microscope (Nikon) equipped with Comet IV ${ }^{\diamond}$ software (Perceptive Imaging, Haverhill, Suffolk, UK). The mean values of the TEM in each cell were computed for each experimental group.

\section{Statistical analysis}

Descriptive statistics were used to characterize the cases and controls. Analysis of variance (ANOVA) was used to compare age and other continuous variables and the Chi-square test was used to compare the categorical variables. For the FLARE assay, the Percent Residual DNA Damage (PRD) was calculated using the following equation:

$\mathrm{PRD}=\mathrm{XH} 2 \mathrm{O} 2+\mathrm{OGG}-\mathrm{XH} 2 \mathrm{O} 2 \mathrm{XH} 2 \mathrm{O} 2 \times 100$. Where $\mathrm{XH}_{2} \mathrm{O}_{2}$ is the mean TEM values for each study subject after treatment with $\mathrm{H}_{2} \mathrm{O}_{2}$, while $\mathrm{X}_{\mathrm{H}_{2}} \mathrm{O}_{2}+O G G$ is the mean TEM values for each study subject after $\mathrm{H}_{2} \mathrm{O}_{2}$ treatment and further incubation with OGG1 enzyme for removal of additional residual damage. Linear regression analysis was conducted to adjust the TEM $\mathrm{H}_{2} \mathrm{O}_{2}+$ OGG1 by TEM $\mathrm{H}_{2} \mathrm{O}_{2}$. The residual values from the regression defined as Residual Damage Linear Regression (RDLR) among the cases and controls were computed using ANOVA. RDLR was dichotomized using the $75^{\text {th }}$ percentile of the controls and estimates of lung cancer risk (OR and 95\% CL) for RDLR adjusted for age, sex and family history of a smoking related cancer were determined.

\section{Results}

\section{Demographics and the study population}

The demographic characteristics of the 30 cases and 90 controls are summarized in Table 1 . No significant differences were observed between cases and the controls did not differ significantly in terms of age, gender or ethnicity. Fifty-two percent of the patients selfreported a family history of smoking-related cancer, compared with $40 \%$ of the current, $59 \%$ of the former and $50 \%$ of the non-smoker controls $(P=0.07)$. Cases had on an average smoked cigarettes for 44.23 years, compared with 42.70 and 35.37 years for current and former smoker controls $(\mathrm{P}>0.05$ and $\mathrm{P}<0.001$, respectively); however both cases and controls (current and former groups) smoked about the same number of cigarettes per day (mean number of cigarettes per day \pm SE for cases $=29.2 \pm 2.5$ and $24.4 \pm 1.75$ and $35.0 \pm 3.3$ for current and former smokers respectively, $\mathrm{P}=0.10$ ).

\section{Measurement of 8-OHdG levels at baseline by ELISA}

Among controls, the current and former smoker controls showed significantly higher levels as compared to non-smoker controls (mean $\pm \mathrm{SE}, 1.99+0.55 \mathrm{ng} / \mathrm{ml}$, $1.68+0.99 \mathrm{ng} / \mathrm{ml}$ versus $0.83+0.62$ respectively, $\mathrm{P}<$ 0.001 ). There was no significant difference between the level of 8-OHdG among the former and current smokers controls $(P=0.28)$. Lung cancer cases had over 2fold higher levels of 8-OHdG than the non-smoker controls (mean $\pm \mathrm{SE}, 2.09+0.91 \mathrm{ng} / \mathrm{ml}$ versus $0.83+0.62$, $\mathrm{P}<0.001$ ); however the difference was not significant when compared to former and current smoker controls $(\mathrm{P}=0.88$ and $\mathrm{P}=0.33$, respectively).

\section{Measurement of DNA damage at baseline by Comet assay}

Table 2 shows the extent of baseline DNA damage measured as TEM. Among controls, the non- and former smokers had significantly lower DNA damage than the current smoker controls (mean $\pm \mathrm{SE}=0.26 \pm 0.11$ and $0.23 \pm 0.09$ versus $0.54 \pm 0.15, \mathrm{P}<0.001)$. There was no significant difference between the level of baseline DNA damage among the non- and former smokers controls ( $\mathrm{P}=0.95)$.

Comparing cases and controls, the baseline levels of DNA damage was significantly different between groups $(0.57 \pm 0.12$ versus $0.35 \pm 0.19, \mathrm{P}<0.001)$. However, when the controls were subdivided by smoking status, the levels of TEM were significantly different between lung cancer cases and non- and former smoker controls only $(\mathrm{P}<0.001)$. There was no difference between the level of baseline DNA damage among the current smoker controls and the lung cancer cases (mean $\pm \mathrm{SE}=$ $0.54 \pm 0.15$ versus $0.57 \pm 0.12$ respectively, $\mathrm{P}=0.83$ )

\section{Measurement of $\mathrm{H}_{2} \mathrm{O}_{2}$-induced DNA damage by Comet assay}

Level of $\mathrm{H}_{2} \mathrm{O}_{2}$-induced DNA damage after an hour incubation (to allow cellular intrinsic repair of damage) 
Table 1 Comparison of demographic and clinical factors among cases and controls

\begin{tabular}{|c|c|c|c|c|c|}
\hline & \multirow[t]{2}{*}{ Cases } & \multicolumn{3}{|c|}{ Controls } & \multirow{3}{*}{ P-value } \\
\hline & & $\begin{array}{l}\text { Current } \\
\text { Smokers }\end{array}$ & $\begin{array}{l}\text { Former } \\
\text { Smokers }\end{array}$ & $\begin{array}{c}\text { Non- } \\
\text { Smokers }\end{array}$ & \\
\hline & $N=30$ & $N=30$ & $N=30$ & $\mathrm{~N}=30$ & \\
\hline Age (mean $\pm \mathrm{SE}$ ) & $62.7 \pm 0.57$ & $63.5 \pm 0.84$ & $61.9 \pm 0.69$ & $58.6 \pm 0.98$ & 0.27 \\
\hline \multicolumn{6}{|l|}{ Gender: N (\%) } \\
\hline Male & 15(50.0) & $20(66.7)$ & $21(70.0)$ & $20(66.7)$ & \\
\hline Female & 15(50.0) & 10(33.3) & $9(30.0$ & 10(33.3) & 0.58 \\
\hline \multicolumn{6}{|l|}{ Ethnicity } \\
\hline Anglo & $30(100.0)$ & 29(96.7) & 25(83.3) & $30(100.0)$ & \\
\hline Non-Anglo & $0(0.0)$ & $1(3.3)$ & $5(16.7)$ & $0(0.0)$ & 0.24 \\
\hline No. of Cigarettes/day Mean \pm SE & $29.2 \pm 2.5$ & $24.4 \pm 1.75$ & $35.0 \pm 3.3$ & $0.0 \pm 0.0$ & $<0.001$ \\
\hline Years smoked Mean \pm SE: & $44.23 \pm 1.39$ & $42.70 \pm 1.46$ & $35.37 \pm 1.58$ & $0.0 \pm 0.0$ & $<0.001$ \\
\hline \multicolumn{6}{|l|}{ Family History Cancer } \\
\hline \multicolumn{6}{|l|}{ N (\%) } \\
\hline No & 14(48.3) & $15(60.0)$ & $12(41.4)$ & $15(50.0)$ & \\
\hline Yes & $15(51.7)$ & $10(40.0)$ & 17(58.6) & 15(50.0) & 0.07 \\
\hline
\end{tabular}

P-values from Chi-square test for association (categorical) or ANOVA (continuous)

is shown in Table 2. The level of TEM in all three groups of controls was significantly different with mean $+\mathrm{SD}=3.2+0.82 ; 5.8+0.31$ and $10.2+0.93$ for nonformer and current smoker controls, respectively. Lung cancer cases had over 6-, 3-and 1-fold higher levels of induced DNA damage than the non-, former and current smoker controls, respectively. The lung cancer cases had the highest level of DNA damage followed by the current smokers (mean $+\mathrm{SD}=19.5+0.41$ versus $10.2+0.93, \mathrm{P}<0.001)$. The non-smokers exhibited the least damage (mean $+\mathrm{SD}=3.2+0.82$ versus $5.8+0.31$, $10.2+0.93, \mathrm{P}<0.001$, for former and current smoker controls, respectively).

\section{Measurement of DNA repair and residual capacity by FLARE assay}

To elucidate the underlying mechanisms underlying the differences in response between the lung cancer cases and the current smoker controls, we used the FLARE assay to measure the repair capacity between the 2 groups. The TEM measured by the FLARE assay is the end result of the $\mathrm{H}_{2} \mathrm{O}_{2}$-induced damage as well as a manifestation of the removal of additional 8-oxoG lesions recognized by the hOGG1 enzyme. Thus the FLARE can be used to measure the residual damage that has not been removed during the initial one hour recovery after $\mathrm{H}_{2} \mathrm{O}_{2}$ treatment. Lung cancer cases had over 2-fold higher levels of DNA damage than the current smoker controls (mean $\pm \mathrm{SD}=44.6 \pm 0.89$ versus $18.4 \pm 1.37, \mathrm{P}<0.001)$. The residual DNA damage among cases and current smoker controls are summarized in Table 3. Comparing cases and current smokers controls revealed significantly lower levels of residual DNA damage in the controls $(\mathrm{P}<0.001)$, thus reflecting more efficient repair capacity compared to the cases.

Figure 1 shows the range of calculated DNA repair capacity in response to $\mathrm{H}_{2} \mathrm{O}_{2}$ treatment (Figure 1A) and $\mathrm{H}_{2} \mathrm{O}_{2}+$ hOGG1 (Figure 1B) among cases and current smokers controls using the $75^{\text {th }}$ percentile of the controls as the cutoff point. Minimal variation in repair was observed among the cases, with about $90 \%$ and $100 \%$ of the cases falling into the poor repair group $(<20 \%)$ in response to $\mathrm{H}_{2} \mathrm{O}_{2}$ treatment alone and $\mathrm{H}_{2} \mathrm{O}_{2}+$ hOGG1 treatments, respectively. Only $1 \%$ of the cases showed a repair capacity over $80 \%$. In contrast, the current controls had a wide range of repair, with $76 \%$ of the control subjects having a repair capacity of $>80 \%$ in response to the $\mathrm{H}_{2} \mathrm{O}_{2}$ treatment and $\mathrm{H}_{2} \mathrm{O}_{2}+$ hOGG1 treatments. Table 2 shows the distribution of residual damage among cases and current controls and determination of

Table 2 Distribution of baseline and $\mathrm{H}_{2} \mathrm{O}_{2}$-induced DNA damage among cases and controls

\begin{tabular}{llllll}
\hline $\begin{array}{l}\text { Tail Extent Moment } \\
\text { Mean } \pm \text { SE }\end{array}$ & $\begin{array}{l}\text { Non- } \\
\text { Smokers }\end{array}$ & $\begin{array}{l}\text { Controls } \\
\text { Smormer }\end{array}$ & $\begin{array}{l}\text { Current } \\
\text { Smokers }\end{array}$ & Cases & Current Smokers \\
& $0.26 \pm 0.11$ & $0.23 \pm 0.09$ & $0.54 \pm 0.15$ & $0.57 \pm 0.12$ & $<0.001$ \\
\hline Baseline DNA damage & $3.2 \pm 0.82$ & $5.8 \pm 0.31$ & $10.2 \pm 0.93$ & $19.5 \pm 0.41$ & $<0.001$ \\
$\mathrm{H}_{2} \mathrm{O}_{2}$ - induced DNA damage & & & \\
\hline
\end{tabular}


Table 3 Distribution of DNA damage and percent residual DNA damage among cases and current smoker controls

\begin{tabular}{|c|c|c|c|c|c|}
\hline \multirow[t]{2}{*}{$\begin{array}{l}\text { Tail Extent Moment } \\
\text { Mean } \pm \text { SE }\end{array}$} & \multirow{2}{*}{$\begin{array}{l}\text { Cases } \\
\text { Current } \\
\text { Smokers }\end{array}$} & \multirow{2}{*}{$\begin{array}{l}\text { Controls } \\
\text { Current } \\
\text { Smokers }\end{array}$} & \multirow[t]{2}{*}{ P-value } & \multirow[t]{2}{*}{$\begin{array}{l}\text { Adjusted } \\
\text { OR }\end{array}$} & \multirow[t]{2}{*}{$95 \% \mathrm{CL}$} \\
\hline & & & & & \\
\hline $\mathrm{H}_{2} \mathrm{O}_{2}+\mathrm{OGG} 1$ & $44.6 \pm 0.89$ & $18.4 \pm 1.37$ & $<0.001$ & & \\
\hline Percent Residual Damage (PRD) & $237.4 \pm 8.7$ & $180.8 \pm 50.7$ & $<0.001$ & & \\
\hline \multicolumn{6}{|c|}{ Residual Damage Logistic Regression (RDLR) } \\
\hline$\leq 75$ th $N(\%)$ & 13(43.3) & $41(75.9$ & & & \\
\hline \multirow[t]{3}{*}{$>75$ th N (\%) } & $17(56.7)$ & $13(24.1)$ & & & \\
\hline & 5.07 & $1.80-14.24$ & & & \\
\hline & & Referent & & 5.07 & $1.80-14.24$ \\
\hline
\end{tabular}

P-value from t-test; TEM RDLR dichotomized by $75^{\text {th }}$ percentile of the controls. Adjusted by age, sex and family history of a smoking-related cancer

risk for lung cancer. After adjustment for age, gender and family history of a smoking-related cancer using linear regression there was a 5-fold increase in risk of lung cancer associated with high levels of residual damage or reduced repair capacity $(\mathrm{OR}=5.07 ; 97 \% \mathrm{CL}=1.80$ 14.24).

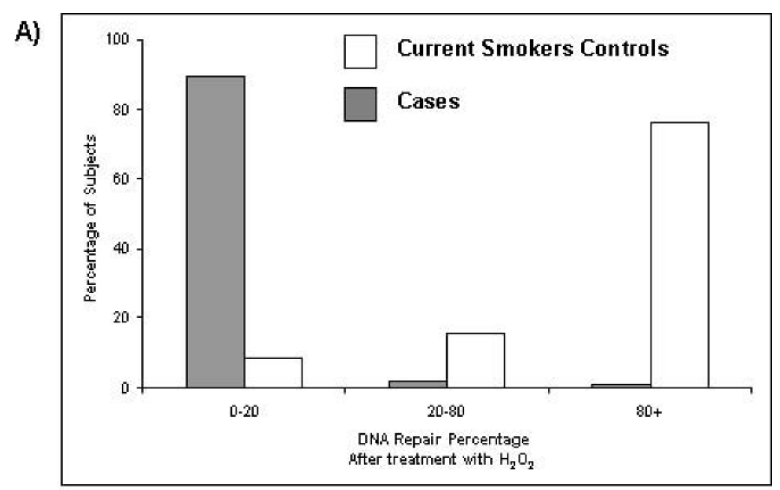

B)

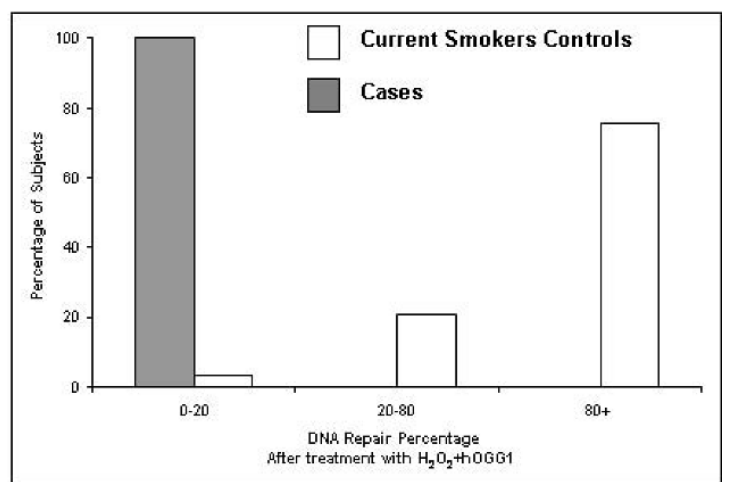

Figure 1 Range of calculated DNA repair capacity measured as TEM among cases and current smoker controls. A) Percentage of DNA repair capacity among current smoker controls and lung cancer cases, after treatment with $\mathrm{H}_{2} \mathrm{O}_{2}$. B) Percentage of DNA repair capacity among current smoker controls and lung cancer cases, after treatment with $\mathrm{H}_{2} \mathrm{O}_{2}+$ hOGG1.

\section{Discussion}

DNA damage generated by ROS produced as byproducts of cellular metabolism has been proposed as a key factor in mutagenesis and cancer process. Superoxide $\left(\mathrm{O}_{2}{ }^{-}\right)$, hydrogen peroxide $\left(\mathrm{H}_{2} \mathrm{O}_{2}\right)$, and the hydroxyl radical $\left(\mathrm{OH}^{-}\right)$are mutagens produced as byproducts of normal metabolism in mitochondria and by ionizing radiation [7]. ROS can induce single-strand breaks and several types of DNA base damage, including fragmented, ring-opened forms and oxidized aromatic derivatives. Among many repair pathways, the BER pathway is the most important cellular protection mechanism responding to oxidative DNA damage induced by ROS [5]. Therefore, increased oxidative DNA damage and reduced BER capacity may play an important role in lung carcinogenesis.

OGG1 is a critical component of the BER pathway required for the removal of 8 -OHdG lesion from DNA exposed to ROS. The impaired repair activity of OGG1 protein was suggested to be a factor contributing to the high somatic mutation rate in human cells, since the accumulation of 8-OHdG cause mutations by mis-pairing with adenine during replication [11-14]. It has also been reported that lower enzymatic levels of OGG1 in peripheral lymphocytes correlated with an increased risk of lung cancer among smokers [23]. In our current study, we elucidate the association between plasma levels of 8-OHdG and the OGG1 repair capacity among lung cancer cases and controls.

Our results demonstrated that baseline DNA damage is similar among lung cancer cases and current smoker controls and is significantly higher than that observed among the former and non-smokers controls. These findings are consistent with other studies showing higher levels of constitutive DNA damage in the form of spontaneous chromosomal aberrations and elevated endogenous single-stranded breaks [30-32] among patients compared to controls. Results from the baseline serum levels of $8-\mathrm{OHdG}$ followed a similar pattern to 
that of the Comet assay where lung cancer cases and current smoker controls had the highest levels of 8OHdG as compared to the former smokers; however, these differences were not significant. Interestingly, the levels of 8-OHdG were significantly lower among nonsmoker controls as compared to the lung cancer cases and current smoker controls. These findings are consistent with studies that have reported that smokinginduced DNA adducts persist for a long time and could still be detectable long after quitting [33,34]. Moreover, numerous reports have associated radicals with smoking-related oxidative stress and DNA damage [23,35,36] since the metabolic activation process leads to the formation of DNA adducts, which are carcinogen metabolites bound covalently to DNA, usually at guanine or adenine. If DNA adducts escape cellular repair mechanisms and persist, they may lead to miscoding, resulting in a permanent mutation. Using a linear regression model we elucidated whether the increase in 8-OHdG levels in cancer patients is related to the increase in residual damage by hOGG1 FLARE among smokers. A significant correlation, $(\mathrm{P}<0.02)$ was found between high levels of 8-OHdG levels at baseline and high levels of residual damage.

Lung cancer is a logical disease for evaluating oxidative damage and the role of free radicals because the etiologic agents for lung cancer are tobacco carcinogens that are known to damage DNA. We therefore used $\mathrm{H}_{2} \mathrm{O}_{2}$ as the ROS-inducing agent in lymphocytes of lung cancer patients and controls in order to measure differential sensitivity (reflected by level of induced DNA damage) and variation in repair capacity. $\mathrm{H}_{2} \mathrm{O}_{2}$ undergoes a Fe (II)-mediated Fenton reaction in the cell, resulting in the formation of the highly reactive hydroxyl radical and other reactive oxygen species which can induce strand breaks in the DNA [37]. Several studies have shown that the repair of single-strand breaks in normal cells is generally rapid, occurring within one hour from exposure $[38,39]$ which is in agreement with results from our DNA repair time course (Additional file 1, Figure S1B). In our experiments, treatment of the cells with $\mathrm{H}_{2} \mathrm{O}_{2}$ followed by a one-hour incubation (to allow strand breaks repair) showed that the level of induced DNA damage was significantly different in all four groups studied, with 3.36-and 1.76-fold increases in detected DNA damage in the cancer cases and current smoker controls respectively as compared to former smoker controls. These results indicate that the peripheral lymphocytes from the three comparison groups may have differential sensitivity to $\mathrm{H}_{2} \mathrm{O}_{2}$ with the lung cancer patients being more sensitive than the current and former smoker controls.

In addition to the increase in sensitivity to $\mathrm{H}_{2} \mathrm{O}_{2}$ induced damage, the lung cancer cases may have a poorer repair capacity than either group of current smoker controls. Several case-control studies have reported that low DNA repair capacity is an independent risk factor for several types of cancers $[27,40,41]$. Likewise, several studies have shown similar increases in DNA damage and decreases in repair efficiency in response to in vitro treatment with chemical mutagens [42-44]. In the current study, $\mathrm{H}_{2} \mathrm{O}_{2}$ treatment followed by a one-hour incubation with hOGG1 enzyme allowed the quantification of the level of residual 8-oxoG in DNA and determination of the repair capacity in the two groups. Our results showed that current smoker controls had a significantly lower level of residual DNA damage compared to the cases. After adjustment for age, gender and family history of a smokingrelated cancer using linear regression there was a 5-fold increase in risk of lung cancer associated with high levels of residual damage/reduced repair capacity $(\mathrm{OR}=5.07$; $97 \% \mathrm{CL}=1.80-14.24)$. Reduced OGG1 activity could be expected to be a risk factor in other smoking-related cancers. However, given the abundance of 8-oxoguanine and the suspected role of oxidative stress in cancer, reduced OGG1 activity might be associated with the risk of some other cancers as well. The excision of 8-oxoguanine residues by OGG1 protects against aberrant adenine-cytosine and guanine-thymine conversions [15] that can lead to heritable mutagenesis, particularly in non-proliferative cells in which lesions accumulate by cell division [45]. OGG1 expression therefore preserves genomic integrity, and it has been shown that Ogg1-deficient mice experience enhanced incidences of mutations and tumor formation [46].

Furthermore, our results showed that the current smoker controls had a relatively wide range of repair capacity (Figures $1 \mathrm{~A}$ and $1 \mathrm{~B}$ ) as compared to the cases, the majority of which fell in the poor repair category. Reduced repair capacity of a particular repair protein may only be revealed when expressed in adverse cellular conditions under oxidative stress. The major risk factor for lung cancer is tobacco smoke and a suboptimal DNA repair could play a crucial role in the susceptibility of the disease. Using the FLARE assay, we were able to identify the small percentage of current smoker controls with poor repair who would be good candidates for intensive follow-up and screening.

\section{Conclusion}

In summary, results from this study suggest that high levels of 8-OHdG are correlated with high levels of oxidative DNA residual damage and suboptimal OGG1 repair capacity all of which were predominantly seen in the lung cancer case group. A limitation of our study is the relatively small sample size of the study groups. However, given the striking differences in damage and repair capacities between groups, it is unlikely that the 
effect is due to the sample size. Large prospective studies are therefore warranted in which robust functional assays such as the ones used in our study could contribute to the identification of individuals. Such an approach, which may be extended to include additional DNA repair pathways, may provide an effective strategy for the prevention of tobacco-related cancers. The simplicity, rapidity and sensitivity of the FLARE assay make it a valuable tool for screening and possibly for prioritizing potential cases for intensive surveillance.

\section{Additional material}

Additional file 1: Supplementary results. Figure $\mathrm{S1}$ : A) Mean cell viability in response to different concentrations of $\mathrm{H}_{2} \mathrm{O}_{2}$. B) Repair over time in a normal cell-line after $60 \mu \mathrm{M}$ treatment with $\mathrm{H}_{2} \mathrm{O}_{2}$.

\section{Acknowledgements}

This work was supported in part by National Cancer Institute grants CA98549, CA129050, CA55769, NIEHS ES07784.

\section{Author details}

${ }^{1}$ The University of Texas M. D. Anderson Cancer Center, Department of Epidemiology, Houston, Texas, USA. 'Kelsey Research Foundation, Houston, Texas, USA.

\section{Authors' contributions}

REZ was responsible for conceiving and designing the study as well as analyzing and interpreting the data and writing the different stages of the manuscript. CMM was responsible for the Comet/FLARE experiments and contributed in the data analysis and drafting the manuscript. AC was responsible for the ELISA assays and contributed in the data analysis. MRS and $A G$ were responsible for coordination of the subject recruitment for the study and participated in data interpretation and manuscript preparation. CEJ was responsible for data analysis and contributed to manuscript preparation. All authors read and approved the final manuscript.

\section{Competing interests}

The authors declare that they have no competing interests.

Financial competing interests:

1. In the past five years have you received reimbursements, fees, funding, or salary from an organization that may in any way gain or lose financially from the publication of this manuscript, either now or in the future? Is such an organization financing this manuscript (including the article-processing charge)? If so, please specify.

Response: No

2. Do you hold any stocks or shares in an organization that may in any way gain or lose financially from the publication of this manuscript, either now or in the future? If so, please specify.

Response: No

3. Do you hold or are you currently applying for any patents relating to the content of the manuscript? Have you received reimbursements, fees,

funding, or salary from an organization that holds or has applied for patents relating to the content of the manuscript? If so, please specify.

Response: No

4. Do you have any other financial competing interests? If so, please specify. Non-financial competing interests: are there any non-financial competing interests (political, personal, religious, academic, ideological, intellectual, commercial or any other) to declare in relation to this manuscript? If so, please specify.

Response: No

Received: 12 April 2010 Accepted: 18 August 2010 Published: 18 August 2010

\section{References}

1. McHugh PJ, Spanswick VJ, Hartley JA: Repair of DNA interstrand crosslinks: molecular mechanisms and clinical relevance. Lancet Oncol 2001, 2(8):483-90.

2. Berwick $M$, Vineis $P$ : Markers of DNA repair and susceptibility to cancer in humans: an epidemiologic review. J Natl Cancer Inst 2000, 7; 92(11):874-97.

3. Loft S, Paulsen HE: Cancer risk and oxidative DNA damage in man. J Mol Med 1996, 74:297-312.

4. Bjelland S, Seeberg E: Mutagenicity, toxicity and repair of DNA base damage induced by oxidation. Mutat Res 2003, 531:37-80.

5. Caporaso N: The molecular epidemiology of oxidative damage to DNA and cancer. J Natl Cancer Inst 2003, 95:1263-1265.

6. Cooke MS, Evans MD, Dizdaroglu M, Lunec J: Oxidative DNA damage: mechanisms, mutation, and disease. FASEB J 2003, 17(10):1195-214.

7. Hayes JD, McLellan LI: Glutathione and glutathione-dependent enzymes represent a co-ordinately regulated defence against oxidative stress. Free Radic Res 1999, 31(4):273-300.

8. Hecht SS: Tobacco smoke carcinogens and lung cancer. J Nat/ Cancer Inst 1999, 91:1194-10.

9. Spitz MR, Wei Q, Dong Q, Amos Cl, Wu X: Genetic susceptibility to lung cancer: the role of DNA damage and repair. Cancer Epidemiol Biomarkers Prev 2003, 12(8):689-98.

10. Deng L, Kimmel M, Foy M, Spitz M, Wei Q, Gorlova O: Estimation of the effects of smoking and DNA repair capacity on coefficients of a carcinogenesis model for lung cancer. Int J Cancer 2009, 124(9):2152-8.

11. Smart DJ, Chipman JK, Hodges NJ: Activity of OGG1 variants in the repair of pro-oxidant-induced 8-oxo-2'-deoxyguanosine. DNA Repair [Amst] 2006, 5(11):1337-45.

12. Dizdaroglu M: Substrate specificities and excision kinetics of DNA glycosylases involved in base-excision repair of oxidative DNA damage. Mutat Res 2003, 531(1-2):109-26.

13. Nakabeppu Y: Regulation of intracellular localization of human MTH1, OGG1, and MYH proteins for repair of oxidative DNA damage. Prog Nucleic Acid Res 2001, 68:75-94, Mol Biol.

14. Kasai $\mathrm{H}$ : Analysis of a form of oxidative DNA damage, 8-hydroxy-2'deoxyguanosine, as a marker of cellular oxidative stress during carcinogenesis. Mutat Res 1997, 387(3):147-63.

15. Moriya M: Single-stranded shuttle phagemid for mutagenesis studies in mammalian cells: 8-oxoguanine in DNA induced targeted G.C $\rightarrow$ T.A transversions in simian kidney cells. Proc Natl Acad Sci USA 1993, 90:1122-6.

16. Valko M, Izakovic M, Mazur M, Rhodes $\mathrm{Cl}$, Telser J: Role of oxygen radicals in DNA damage and cancer incidence. Mol Cell Biochem 2004, 266(12):37-56.

17. Bartsch $\mathrm{H}$ : DNA adducts in human carcinogenesis: Etiological relevance and structure-activity relationship. Mut Res Rev Genet Toxicol 1996, 340:67-79

18. Hansen WK, Kelley MR: Review of mammalian DNA repair and translational implications. J Pharmacol Exp Ther 2000, 295:1-9.

19. Minowa O, Masanori Hirano T, Monden Y, Nakai S, Fukuda M, Itoh M, Takano H, Hippou Y, Aburatani H, Masumura K: Mmh/Ogg1 gene inactivation results in accumulation of 8-hydroxyguanine in mice. Proc Natl Acad Sci USA 2000, 97:4156-4161.

20. Collins AR, Ai-guo M, Duthie SJ: The kinetics of repair of oxidative DNA damage [strand breaks and oxidised pyrimidines] in human cells. Mutat Res 1995, 36(1):69-77.

21. Kamiya H, Yamaguchi A, Suzuki T, Harashima $H$ : Roles of specialized DNA polymerases in mutagenesis by 8-hydroxguanine in human cells. Mutat Res 2010, 686(1-2):90-95.

22. Shen J, Deininger $P$, Hunt JD, Zhao H: 8-Hydroxy-2'-deoxyguanosine [8$\mathrm{OH}-\mathrm{dG}]$ as a potential survival biomarker in patients with nonsmall-cell lung cancer. Cancer 2007, 109(3):574-80.

23. Paz-Elizur $T$, Krupsky M, Blumenstein S, Elinger D, Schechtman E, Livneh Z: DNA repair activity for oxidative damage and risk of lung cancer. $J$ Natl Cancer Inst 2003, 95(17):1312-9.

24. Fairbairn DW, Olive PL, O'Neill KL: The comet assay: a comprehensive review. Mutat Res 1995, 339(1):37-59.

25. Singh NP, McCoy MT, Tice RR, Schneider EL: A simple technique for quantitation of low levels of DNA damage in individual cells. Exp Cell Res 1988, 175(1):184-91. 
26. Gaivão I, Piasek A, Brevik A, Shaposhnikov S, Collins AR: Comet assay-based methods for measuring DNA repair in vitro; estimates of inter- and intra-individual variation. Cell Biol Toxicol 2009, 25(1):45-52.

27. Marcon F, Andreoli C, Rossi S, Verdina A, Galati R, Crebelli R: Assessment of individual sensitivity to ionizing radiation and DNA repair efficiency in a healthy population. Mutat Res 2003, 541(1-2):1-8.

28. Rosenquist TA, Zharkov DO, Grollman AP: Cloning and characterization of a mammalian 8-oxoguanine DNA glycosylase. Proc Natl Acad Sci USA 1997, 94:7429-7434.

29. Smith CC, O'Donovan MR, Martin EA: hOGG1 recognizes oxidative damage using the comet assay with greater specificity than FPG or ENDOIII. Mutagenesis 2006, 21(3):185-90.

30. Udumudi A, Jaiswal M, Rajeswari N, Desai N, Jain S, Balakrishna N, Rao KV, Ahuja YR: Risk assessment in cervical dysplasia patients by single cell gel electrophoresis assay: a study of DNA damage and repair. Mutat Res 1998, 412(2):195-205

31. Blasiak J, Arabski M, Krupa R, Wozniak K, Rykala J, Kolacinska A, Morawiec Z, Drzewoski J, Zadrozny M: Basal, oxidative and alkylative DNA damage, DNA repair efficacy and mutagen sensitivity in breast cancer. Mutat Res 2004, 554(1-2):139-48.

32. Vodicka P, Polivkova Z, Sytarova S, Demova H, Kucerova M, Vodickova L, Polakova V, Naccarati A, Smerhovsky Z, Ambrus M, Cerna M, Hemminki K: Chromosomal damage in peripheral blood lymphocytes of newly diagnosed cancer patients and healthy controls. Carcinogenesis 2010.

33. Wiencke JK, Thurston SW, Kelsey KT, Varkonyi A, Wain JC, Mark EJ, Christiani DC: Early age at smoking initiation and tobacco carcinogen DNA damage in the lung. J Natl Cancer Inst 1999, 91(7):614-9.

34. Chen L, Wang M, Villalta PW, Luo X, Feuer R, Jensen J, Hatsukami DK, Hecht SS: Quantitation of an acetaldehyde adducts in human leukocyte DNA and the effect of smoking cessation. Chem Res Toxicol 2007, 20(1):108-13.

35. Mizoue T, Kasai H, Kubo T, Tokunaga S: Leanness, smoking, and enhanced oxidative DNA damage. Cancer Epidemiol Biomarkers Prev 2006, 15(3):582-5.

36. Hatt L, Loft S, Risom L, Møller P, Sørensen M, Raaschou-Nielsen O, Overvad K, Tjønneland A, Vogel U: OGG1 expression and OGG1 Ser326Cys polymorphism and risk of lung cancer in a prospective study. Mutat Res 2008, 639(1-2):45-54

37. loyd DR, Phillips DH: Oxidative DNA damage mediated by copper[II], iron [II] and nickel[II] fenton reactions: evidence for site-specific mechanisms in the formation of double-strand breaks, 8-hydroxydeoxyguanosine and putative intrastrand cross-links. Mutat Res 1999, 424(1-2):23-36.

38. Collins AR, Dusinská M: Oxidation of cellular DNA measured with the comet assay. Methods Mol Biol 2002, 186:147-59.

39. Torbergsen AC, Collins AR: Recovery of human lymphocytes from oxidative DNA damage; the apparent enhancement of DNA repair by carotenoids is probably simply an antioxidant effect. Eur J Nutr 2000, 39(2):80-5.

40. Hjertvik M, Erixon K, Ahnström G: Repair of DNA damage in mammalian cells after treatment with UV and dimethyl sulphate: discrimination between nucleotide and base excision repair by their temperature dependence. Mutat Res 1998, 407(2):87-96.

41. Zheng $Y L$, Loffredo CA, Yu Z, Jones RT, Krasna MJ, Alberg AJ, Yung R, Perlmutter D, Enewold L, Harris CC, Shields PG: Bleomycin-induced chromosome breaks as a risk marker for lung cancer: a case-control study with population and hospital controls. Carcinogenesis 2003, 24(2):269-74

42. Schmid O, Speit G: Genotoxic effects induced by formaldehyde in human blood and implications for the interpretation of biomonitoring studies. Mutagenesis 2007, 22(1):69-74.

43. Speit G, Hartmann A: The comet assay: a sensitive genotoxicity test for the detection of DNA damage and repair. Methods Mol Biol 2006, 314:275-86.

44. Lacoste S, Castonguay A, Drouin R: Repair kinetics of specific types of nitroso-induced DNA damage using the comet assay in human cells. Mutat Res 2007, 624(1-2):18-30.

45. Oka S, Ohno M, Tsuchimoto D, Sakumi K, Furuichi M, Nakabeppu Y: Two distinct pathways of cell death triggered by oxidative damage to nuclear and mitochondrial DNAs. EMBO J 2008, 27(2):421-32.
46. Klungland A, Rosewell I, Hollenbach S, Larsen E, Daly G, Epe B, Seeberg E, Lindahl T, Barnes DE: Accumulation of premutagenic DNA lesions in mice defective in removal of oxidative base damage. Proc Natl Acad Sci USA 1999, 96(23):13300-5.

\section{Pre-publication history}

The pre-publication history for this paper can be accessed here: http://www.biomedcentral.com/1471-2407/10/439/prepub

doi:10.1186/1471-2407-10-439

Cite this article as: El-Zein et al:: Rapid method for determination of DNA repair capacity in human peripheral blood lymphocytes amongst smokers. BMC Cancer 2010 10:439.

\section{Submit your next manuscript to BioMed Central and take full advantage of:}

- Convenient online submission

- Thorough peer review

- No space constraints or color figure charges

- Immediate publication on acceptance

- Inclusion in PubMed, CAS, Scopus and Google Scholar

- Research which is freely available for redistribution

Submit your manuscript at www.biomedcentral.com/submit
C) Biomed Central 